\title{
The study of sustainability report disclosure aspects and their impact on the companies' performance
}

\author{
Aisyah Farisa Caesaria ${ }^{1, *}$, and $B$. Basuki ${ }^{1}$ \\ ${ }^{1}$ Faculty of Economics and Business, Universitas Airlangga, Surabaya, Indonesia
}

\begin{abstract}
This research is aimed to invetigate the effect of Sustainability Report Disclosure to the Firm's market performance. Three material aspects disclosed in the Sustainability report such as economics (EC), environmental (EN), and social aspect (SC) are used as the independent variables in this research and, furthermore, the dependent variable is the market performance which is proxied by using Tobin's Q. This researchs was conducted using mainstream positivistic quantitative methods to test the three formulated hypotheses. The samples taken were 44 observations from all listed companies in the Indonesia Stock Exchange (IDX) that reveal sustainability reports using GRI-G4 guidelines. This guideline is the latest version issued by the Global Reporting Innitiative (GRI), which can be implemented starting from 2013. The results showed that economicss, environmental, and social aspects have positively significant influence to the companies market performance. The practical implication of this research is the value given by society in term of the company image to those companies which disclosure their activities related to economics, social, and environment activities affects their company performance.
\end{abstract}

Keywords: Sustainability report, economics disclosure, environmental disclosure, social disclosure, market performance, GRI-G4

\section{Background}

Sustainability has been the center of discussion in international publication for almost two decades [1]. The concept of sustainability gives attention not only on profit, but also on long-term business sustainability. Sustainability focuses not only on the interests of investors and shareholders, but also on the responsibility of stakeholders who either directly or indirectly affected or related to the business. Businesses awareness towards the trend on sustainable development is driven by the stakeholders needs. According to [2], there is increasing pressure from many groups of stakeholder into the company to reduce negative impacts on the environment and society, as well as demands for more transparent and accountable.

Three aspects of sustainability efforts were disclosed and reported: people-social, planet-environmental, economicsprofit. Sustainability reporting of these aspects help organizations to set goals, measure performances and manage changes in order to make their operations more sustainable [3]. In addition, increasing the company that makes reporting separately through sustainability reporting can be seen as a strategy to communicate the company's performance in the company's efforts to be accountable to stakeholders.

The sustainability report has been practiced since 2000, and the GRI guidelines have been used as a reference to the report of the company. Up to 2014, there are 86 companies in Indonesia that have reported sustainability report based on the GRI Guidelines. These guidelines are used by [4], sustainability report is positioned as an additional report on the financial statements. In Indonesia, the implementation of social and environmental responsibility contained in the [5]. The Law stated that any entity run its business in the field and / or related to the natural resources required to implement the Social Responsibility and Environmental budgeted and accounted for as company's costs. Further provisions stipulated in [18]. [18] states that the company is required to disclose the implementation of social and environmental responsibility in their annual report and be accountable to the Shareholders General Meeting.

The increasing need for sustainability report is also followed by increasing companies reports have created the amount of research on the disclosure on sustainability report grow and become a hot topic to be discussed. However, several studies related to the sustainability report showed inconsistent results. Research by [6], as well as [7] states that the three aspects of sustainability report has a significant positive effect on the enterprise market performance, either partially or simultaneously. On the other hand, research by [8] expressed a negative influence on such things. Moreover, [9] found a neutral influence, and few other studies including [10], [2], as well as [11] found the different effect. All these differences are the research gaps which make researchers interested in conducting this research to examine how the influence of each aspect of the sustainability report disclosure. This study used sample of all companies listed in the

\footnotetext{
*Corresponding author: aisyahfarisa@gmail.com
} 
Indonesia Stock Exchange in 2013-2014. Research years of 2013-2014 were selected, because guidelines for disclosure of sustainability report were most widely used in these periods; GRI G-4 starts to be implemented in 2013.

The research problem: Is the expression of economics, environmental, and social aspects in the Sustainability Report influence the companies' market performances? The purpose of the study, furthermore, is to obtain empirical evidence regarding the impact of those aspects in the companies' performance.

\section{Theoretical and development hypothesis}

Based on the Stakeholders Theory, the main purpose of the company disclosure on the performance of sustainability is to increase the availability of information, as a form of responsibility to its stakeholders. These responsibilities, according to the Theory of Legitimacy, arise because of the "social contract" requires that all activities of the company can be accepted by outsiders as a legitimate. Therefore, in accordance to the Signaling Theory, a company whose aim is to give a signal that they are good corporate, will disclose more than before because competitors may also have the same pressures to make disclosure. Disclosure on the sustainability report was initially described by the concept of the Triple Bottom Line (TBL) proposed by [12]. Based on this concept, there are three aspects should be disclosed by companies in the sustainability report: economics (profit), environment (planet), and social aspect (people).

\subsection{Economics aspects disclosure relationship with the company's performance}

The information contained in the economics dimension (EC) convince stakeholders about potential competitive capital resources and low level of risk [11]. The disclosure of these aspects can prove their company's contribution to the economics development of local communities. Sustainability disclosure report is seen as a positive action by the company to maintain trust and good relations with investors and creditors that will invest in the company. The confidence feeling of investors and creditors in the corporate accountability will enhance the company's reputation or image. Consequently, it will increase in market performance of a company for the following years.

H1: Economics Aspects Disclosure (EC) significantly affects the company's market performance.

\subsection{Environmental aspects disclosure relationship with the company's performance}

Based on the Legitimacy theory, the company responded to public pressure by using environmental disclosure [13]. Environment category in GRI G4-2013 covers the impacts associated with the inputs (such as energy and water) and outputs (such as emissions, effluent and waste). The use of input and output generated by the company triggers a variety of environmental problems. Then the company is required to prevent, minimize, and repair the damage as a form of concern and responsibility to the environment. Transparency of the company's contribution to protect the environment will make stakeholders know and understand the things of what has been done as a form of concern and responsibility to the environment. Then the company will receive recognition and support from its stakeholders, so that the company's business operations will run more smoothly. The second hypothesis can be formulated as follows:

H2: Environmental Aspects Disclosure (EN) significantly affects the company's market performance.

\subsection{Disclosure Social Aspects Relations with the Company's Performance}

[14] stated that the company's concern increased in the focus of social issues, while maximizing the economy performance to satisfy shareholders and undertake social responsibility for the benefit of society. By revealing the social aspects of the sustainability report means the company will also support many issues of the international organization concern. Social responsibility is not only for external, but also internal stakeholders. The responsibility to the internal side means the company is required to pay attention to employee health and safety, equality of opportunity in competition between male and female employees, and human rights aspects. Meanwhile, to external parties, the company is required to promote anti-corruption policies, anti-competitive and monopolistic practices that can harm the stakeholders and labeling products for the health and safety of customers. According to [15], implement and report on social responsibility towards stakeholders can not only increase the price of company's stock, but also improve the welfare and employee loyalty, lower turnover rate of employees that can lead to increased productivity. When the productivity increases, the company can further enhance the image or company's value in the eyes of all stakeholders. The third formulated hypothesis is:

H3: Social Aspects Disclosure (SO) significantly affects the company's market performance.

\section{Research methods}

This study uses a quantitative approach to test those hypotheses. The analytical method used by using multiple linear regressions.

\subsection{Company market performance}

Market performance is a description of certain conditions achieved by the company as a form of reciprocal market perception. Market performance of companies can also be interpreted as the value of the company using Tobin's Q. 


\subsection{Sustainability report disclosure}

Disclosure in the Sustainability Report is an expression that contains information of financial performance, and nonfinancial information. In this study, researchers used the latest version of the guidelines for the sustainability report disclosure, namely the $4^{\text {th }}$ version of the Guidelines (GRI-G4) which was released in 2013. Of the three categories, there are a total of 91 items that must be disclosed, which consists of 9 items of economics aspects, 34 items for environmental aspects, and 48 items of social aspects. These three variables disclosure in the sustainability report was measured through the Sustainability Report Disclosure Index (SRDI). The calculation is performed by using a dummy which was given a score of 1 if an item is disclosed and 0 if not disclosed. After scoring on all items in the sustainability report, scores are then summed to obtain the overall score of the company. SRDI calculation formula for each aspect of sustainability report:

$\mathrm{SRDI}_{\mathrm{EC}}=\mathrm{V}_{\mathrm{EC}} / \mathrm{M}_{\mathrm{EC}} ; \mathrm{SRDI}_{\mathrm{EN}}=\mathrm{V}_{\mathrm{EN}} / \mathrm{M}_{\mathrm{EN}} ; \mathrm{SRDI}_{\mathrm{SC}}=\mathrm{V}_{\mathrm{SC}} / \mathrm{M}_{\mathrm{SC}}$

$\mathrm{V}$ is number of item disclosed of every aspect, and $\mathrm{M}$ is number of item stated in GRI G4

Data collection procedures used are documentation and literature study. The literature sources used is from journals, through the electronic media, such as softfile financial statements of the BEI's website www.idx.co.id, softfile sustainability report on the website http://database.globalreporting.org, and internet sites.

The research population is all companies listed on the Indonesian Stock Exchange (BEI) in the period of 20132014. Purposive sampling method used to select samples based on certain considerations in accordance with the research purpose. The criteria established are: (1). All companies listed in Indonesia Stock Exchange (BEI); (2). Publish a sustainability report; (3). Sustainability reports based on the GRI Guidelines G4 in consecutive period 2013-2014; (4). The Company presents the financial statements other than in IDR. Based on these criteria, 22 companies met to be chosen as samples during two-year research periods since GRI-G4 began to be used in 2013. Then the number of samples became 44 companies. However, there are 2 outliers of data so the number of samples became 42 companies.

\section{Results and discussion}

The results of statistical test are as follows:

\begin{tabular}{|c|c|c|c|c|c|c|}
\hline \multirow{2}{*}{\multicolumn{2}{|c|}{ Model }} & \multicolumn{2}{|c|}{$\begin{array}{c}\text { Unstandardized } \\
\text { Coefficients }\end{array}$} & \multirow{2}{*}{$\begin{array}{c}\begin{array}{c}\text { Standardized } \\
\text { Coefficients }\end{array} \\
\text { Beta }\end{array}$} & \multirow[t]{2}{*}{$\mathrm{t}$} & \multirow[t]{2}{*}{ Sig. } \\
\hline & & $\mathrm{B}$ & Std. Error & & & \\
\hline \multirow[t]{4}{*}{1} & (Constant) & $-1,531$ & ,466 & & $-3,286$ &, 002 \\
\hline & $\mathrm{EC}$ & 1,707 & ,719 & ,316 & 2,375 &, 023 \\
\hline & EN & 1,145 &, 531 & ,280 & 2,155 &, 038 \\
\hline & $\mathrm{SC}$ & 1,950 &, 890 & ,311 & 2,192 &, 035 \\
\hline \multicolumn{2}{|c|}{$\mathrm{F}$} & \multicolumn{5}{|c|}{15,570} \\
\hline \multicolumn{2}{|c|}{ Sig. } & \multicolumn{5}{|c|}{0,000} \\
\hline \multicolumn{2}{|c|}{$\mathrm{R}$} & \multicolumn{5}{|c|}{0,743} \\
\hline \multicolumn{2}{|c|}{$\mathrm{R}^{2}$} & \multicolumn{5}{|c|}{0,551} \\
\hline \multicolumn{2}{|c|}{ Durbin-Watson } & \multicolumn{5}{|c|}{1,719} \\
\hline
\end{tabular}

The above table shows that, firstly, the disclosure of Economics aspect (EC) has a positive and significant impact on the market performance of the company. These results are consistent and support the research by [6], and [7]. This proves that the disclosure of the economics aspects in sustainability report improve market performance since the disclosure of these aspects can prove their company's contribution to the development of the global economy and local communities. Secondly, the Disclosure of Environmental aspects (EN) also has a positive and significant impact on the market performance of the company. This is consistent with research [16], [2] and [7]. [16] states that the disclosure of environmental performance will positively enhance the company reputation, in which increase the company's market value. This proves that the disclosure of environmental aspects in sustainability report can improve market performance since the disclosure of these aspects can prove the company's concern to environmental conditions associated with its operations. Lastly, the Disclosure social aspect (SC) has a positive and significant impact on the market performance of companies (Tobin's Q). These results are consistent with studies [17], [2], [7] and [10] which states that disclosure of the social aspect of increasing Tobin's Q. This proves that the disclosure of the social aspects of the sustainability report can improve the performance of the enterprise market. By providing a social contribution, the company will have the image of a good performance in the eyes of the market. The results show that the disclosure of each aspect of economics, environmental and social of the company will increase the company's market performance in the future. 


\section{Conclusions, implications and suggestions}

\subsection{The conclusions are:}

1. Disclosure of the company on aspects of economics, environmental, and social in the Sustainability report turned out to have a significant influence and the market performance of the company. These three aspects will be able to demonstrate their company's contribution to the economics development of both global and local, to prove the existence of the company's concern for the environment, as well as their social contribution to the community and it will enhance the company image in the eyes of the public, thus increasing the company's market performance.

2. The results support some previous research which has found that the higher the disclosure aspects of the sustainability report, namely the economics, environmental and social will lead to improved performance of the enterprise market. Thus, if the company intends to attract the attention of the market trends in performance, the company can optimize these three aspects of sustainability disclosure report.

\subsection{Implication of the study}

The practical implication of this study is that is that the company must pay attention to the importance of social, economics, and environmental disclosure in the sustainability report. Business people turned out to pay attention to such disclosure, and they judge to give "value good image". A good image is what helps improve the performance of the enterprise market.

\subsection{Suggestion}

1. Future studies are expected to use more samples and representative, also the length of study period need to be expanded.

2. In calculating the company's market performance should use more relevant market value data, ie the value after the date of publication of sustainability report.

3. Further research is expected to examine the influence of aspects of sustainability report on the performance of companies using other measurement tools or add new variables and involve not only secondary data, but also involves other data, such as the behavior of the manager / owner or shareholder and investor response.

\section{References}

1. Stenzel, P. L. Sustainability, The Triple Bottom Line, and The Global Reporting Initiative. Global Edge Business Review, Vol. 4 (6) (2010)

2. Hussain, N. Impact of Sustainability Performance on Financial Performance: An Empirical Study of Global Fortune (N100) Firms. Ca' Foscari University of Venice Working Paper, No. 2015/01 (2015)

3. Global Reporting Initiative. G4 Sustainability Report Guidelines: Reporting Principles and Standard Disclosure. Global Reporting Initiative. (2013)

4. Ikatan Akuntan Indonesia. Penyataan Standar Akuntansi Keuangan No. 1 (Revisi 2015): Penyajian Laporan Keuangan. Jakarta (2015)

5. Undang-undang No.40 Tahun 2007 Tentang Perseroan Terbatas (Law No. 40 Year 2007 Article 74 of the Limited Company) (2007)

6. Waworuntu, S.R., et al. CSR and Financial Performance Analysis: Evidence from Top ASEAN Listed Companies. Procedia Social and Behavioral Science, 164 : 493-500 (2014)

7. Ioannou, I., and G. Sarafeim. The Consequences of Mandatory Corporate Sustainability Reporting: Evidence From Four Countries. Harvard Business School Research Working Paper, No. 11-100 (2014)

8. Wibowo, I. and A.F. Sekar. Dampak Pengungkapan SR terhadap Kinerja Keuangan dan Pasar Perusahaan. Jurnal Simposium Nasional Akuntansi XVII. Lombok. 24-27 September (2014)

9. McWilliams, A., and S. Donald. Corporate Social Responsibility: A Theory of The Firm Perspective. The Academy of Management Review, Vol. 26(1): 117-127 (2001)

10. Burhan, Annisa H. N. \& W. Rahmanti. The Impact of Sustainability Reporting on Company Performance. Journal of Economicss, Business and Accountancy Ventura, Vol. 15 (2): 257-272 (2012)

11. Tarigan, J. and S. Hatane. Pengungkapan Sustainability Report Terhadap Kinerja Keuangan. Jurnal Akuntansi \& Keuangan, Vol. 16 (2): 88-110 (2014)

12. Elkington, J. Cannibals with Forks: The Triple Bottom Line of 21st Century Business, Oxford: Capstone (1997)

13. Schadewitz, H., and N. Mikael. Communication Via Responsibility Reporting and its Effect on Firm Value in Finland. John Wiley \& Sons, Ltd and ERP Environment Publication (2010)

14. Rodriguez, M., \& Fernandez. Social Responsibility and Financial Performance: The Role of Good Corporate Governance. BRQ Business Research Quarterly (2015)

15. Ernst \& Young Global Limited. Sustainability Reporting-The Time is Now. EY Publication (2014) 
16. Dowell, G., et al. Do Corporate Global Environmental Standards Create or Destroy Market Value?. Management Science, 46 (8): 1059-1074 (2000)

17. Cormier, H., et al. Attributes of Social and Human Capital Disclosure and Information Asymmetry between Managers and Investors. Canadian Journal of Administrative Sciences, 26: 71-88 (2009)

18. Peraturan Pemerintah No. 47 Tahun 2012 Tentang Pelaksanaan Tanggung Jawab Sosial Lingkungan Perseroan (the Government Regulation (PP) No. 47 of 2012 on the Implementation of the Environment Social Responsibility Company) (2012) 